bined with rheumatoid arthritis a clinical dental examination of 100 patients with indicated pathology aged from 34 to 62 years old has been conducted. They had appealed for aid to therapeutic dentistry department of Vinnytsia CCH №1 and therapeutic dentistry department of VNMU named after Pirogov. The control group included 25 practically healthy persons of the same age with healthy oral mucosa.

Research results. Among the 100 examined patients with lesions of the oral mucosa 36 people (36\%) had chronic catarrhal stomatitis, $25(25 \%)$ - superficial form of desquamative glossitis, $20(20 \%)$ - hyperplastic form of desquamative glossitis, and 19 (19\%) of them suffered from atrophic glossitis. It was established that conditions of the oral mucosa in significant degree depends on the nature, duration and severity of accompanying disease.

Conclusion. Considering the fact that diffuse lesions of connective tissue is the main pathogenetic link in rheumatoid arthritis it could be stated, that accompanying pathology affects negatively the oral mucosa and the course of detected oral diseases. Atrophic glossitis, which was observed in $19 \%$ of patients out of the the total number of examined patients is associated with a pronounced atrophy of tongue papillae with similar genesis.

Abundant microflora in the oral cavity without sanation, a decrease of salivation and chronic traumas contribute to increasing inflammation and appearance of subjective feelings in patients with desquamative glossitis.

Key words: diseases of the oral mucosa, rheumatoid arthritis, clinical examination.

Pyrohov National Medical University (Vinnytsia)

\title{
И.Д. Ладная
}

\section{ЭФФЕКТИВНОСТЬ ЛЕЧЕНИЯ НЕЙРОПАТИИ ЛИЦЕВОГО НЕРВА МЕТОДОМ РЕФЛЕКСОТЕРАПИИ}

Харьковская медицинская академия последипломного образования

Резюме. Изучены оптимальные сроки и курсы лечения больных с нейропатиями лицевого нерва различной степени тяжести. Комплексное лечение нейропатий лицевого нерва проводилось с использованием рефлексотерапии (иглоукалывание). По результатам исследования определены оптимальные сроки и количество курсов. Метод рефлексотерапии является более эффективным при обращении пациентов в более ран-

Введение. Болезни нервной системы в настоящее время являются значимой медикосоциальной проблемой $[9,16,18]$. Актуальным вопросом неврологии остается нейропатия лицевого нерва, обусловленная значительной распространенностью, особенностями клинического течения и его последствиями, что во многом снижает качество жизни и отрицательно влияет на психоэмоциональную сферу больных [12]. Приводятся данные, что распространенность нейропатии лицевого нерва составляет 13-24 случая на 100 тыс. населения [11]. Поражение лицевого нерва является наиболее распространенной проблемой в неврологии, которая приводит к стойким эстетическим дефектам, проявляющимся, прежде всего, в виде асимметрии лица [13].

Наиболее частыми причинами, вызывающими раздражение нервов или их вегетативных ганглиев, являются воспаление, травма и компрессия [17]. Предполагают, что поражение лицевого нерва связано с вирусной инфекцией, также ний период заболевания. При длительно существующих нейропатиях необходимо провести пять и более курсов рефлексотерапии. Эффект лечения зависел от длительности заболевания и времени начала лечения.

Ключевые слова: нейропатии, лицевой нерв, рефлексотерапия.

к факторам, способствующим развитию нейропатии лицевого нерва, относится: переохлаждение, повышение артериального давления, воспалительные заболевания уха и горла. Относительно нередкой причиной поражения нерва в стоматологической практике бывает анестезия нижнего альвеолярного нерва [18].

В неврологии применяются различные методы лечения нейропатий лицевого нерва, включая медикаментозное лечение и физиотерапию: электрическое поле УВЧ, переменное магнитное поле, элекростимуляция, ультразвук, тепловое лечение, лечебную физкультуру [6, 7].

При лечении традиционными методами восстановление функции лицевого нерва наступает в 40-60 \% случаев, поэтому продолжается поиск эффективных схем лечения невропатий лицевого нерва $[14,15]$.

Одним из признанных методов лечения нейропатий лицевого нерва является рефлексотерапия, которая имеет минимум противопоказаний и 
не имеет побочных явлений $[1,2]$. Современная рефлексотерапия является эффективным методом лечения, улучшающим качество жизни за счет воздействия на центральную нервную систему, нейрогуморальную, эндокринную и иммунную [11] системы.

Акупунктурные точки представляют собой биологически активные точки в виде небольших участков кожи и подкожной основы, в которых имеется комплекс взаимосвязанных микроструктур (сосуды, нервы, клетки соединительной ткани) [2].

Эффективная работа рефлексотерапии основана на воздействии иглами на акупунктурные точки разной глубины с учетом разного угла наклона, времени экспозиции и способа извлечения игл, что обычно имеет значение для избирательного влияния на отдельные органы и системы $[1,2]$.

Цель исследования. Определить оптимальные сроки и курсы лечения больных с нейропатиями лицевого нерва различной степени тяжести.

Материал и методы. Обследование пациентов проводилось в ЦКЛ №5 «Укрзалізниці» г. Харькова с 2009 до 2014 гг. В исследовании принимали участие 232 пациента. Диагноз нейропатии лицевого нерва выставлялся при наличии характерных жалоб, анамнеза, данных объективного осмотра и обследований. Длительность заболевания составляла от 3,9 до 44,5 дней.

В соответствии со степенью дисфункции лицевого нерва были выделены три группы: I группа обследованых составляла 141 (60,78\%) пациент, II группа - 74 (39,1 \%), III группа - 17 $(7,33 \%)$. Для выявления степени дисфункции лицевого нерва использовалась шкала HouseBrackman (1985). Распределение групп по шкале представлено в табл. 1 .

Распределение мужчин и женщин по группам составляло, соответственно: в I группе - 57 и 84; во II группе - 33 и 41; в III группе - 8 и 9. Возраст больных был сопоставим по всем группам: $36 \pm 7,3$ лет (I группа), $38 \pm 7,1$ лет (II группа), $34 \pm 6,2$ лет (III группа).

Диагностика пациентов включала сбор анамнеза, анализ лица в статическом положении, мимические пробы, оценку рефлексов, степени асимметрии и фотодокументирование. Проводились инструментальные методы - ЭМГ (электромиография) и МРТ головного мозга.

Рефлексотерапия назначалась на фоне базовой медикаментозной терапии - противовоспалительные препараты (глюкокортикоиды, нестероидные противовоспалительные препараты); противоотечные (фуросемид, лазикс, диакарб); спазмолитические; сосудорасширяющие (препараты никотиновой кислоты, L-лизина эсцинат, эсполипон); анальгетики; витамины группы В.

Была составлена следующая схема рефлексотерапии: каждый курс составлял семь процедур, проводившихся ежедневно, второй курс на- значался через пять-семь после прохождения первого, 3-й - через 10-14 дней, 4-й - через 21-30 дней, последующие курсы при необходимости повторяли через 45-60 дней.

Для рефлексотерапии были использованы периферические точки акупунктуры, находящиеся на руках и ногах и местные точки на лице. Время экспозиции иглы составляло 20-25 минут на дистальных точках. Точки использовали на лице по возбуждающей методике от 1 до 5 минут, время воздействия увеличивали при каждом последующем курсе.

Точки акупунктуры при лечении нейропатий лицевого нерва представлены в табл. 2.

Результаты исследования и их обсуждение. Клиническое обследование пациентов I группы показало, что у 93 пациентов была установлена легкая дисфункция лицевого нерва, при которой обнаруживались едва заметные синкинезии и легкая ассиметрия рта при улыбке. Умеренная дисфункция у 43 пациентов характеризовалась выраженной ассиметрией и заметными синкинезиями, отмечалась умеренная ассиметрия рта при улыбке. Больные отмечали легкие парестезии в области уха. Двигательные функции мышц с зажмуриванием глаза, подниманием брови и наморщиванием лба сохранялись, но - с меньшей силой, чем на здоровой стороне. Рот едва заметно перетягивался на здоровую сторону. Больной мог надуть щеку, но с меньшей силой, чем со здоровой противоположной стороны.

У 74 пациентов II группы были выявлены признаки выраженной ассиметрии лица и рта в покое, обнаружены выраженные синкинезии и спазмы, что соответствовало средней степени дисфункции. Больные жаловались на умеренные боли и парестезии в области уха и сосцевидного отростка, снижение функции слезоотделения, расстройство вкуса и слюноотделения. Надувание щеки с пораженной стороны было слабым; пациенты не могли свистеть. Попытка закрыть глаз приводила к неполному закрытию, при этом видна была полоска склеры в 1-2 мм. Сморщивание лба и нахмуривание брови было незначительным.

В III группе у 10 обследованных была отмечена выраженная дисфункция, при этом отмечались слабые движения углом рта, пациенты не могли закрыть глаз, в целом движения на пораженной стороне были едва заметны. У семи пациентов была диагностирована тотальная дисфункция с полным отсутствием движений и снижением мышечного тонуса. Уменьшение слезоотделения у больных сопровождалось появлением ксерофтальмии, высказывались жалобы на отсутствие вкуса и слюноотделения. Попытка надуть щеку была слабая; свистеть пациенты не могли; глаз закрывался не полностью - была видна полоска склеры в 3-5 мм. Сморщивание лба было едва заметным. Наблюдались незначительные движения при попытке нахмурить брови.

Анализ результатов лечения показал, что введение в схему лечения двух курсов рефлексо- 
Распределение групп по шкале House-Brackman (1985)

\begin{tabular}{|c|c|c|}
\hline Точка & Назначение & Группа \\
\cline { 1 - 2 } & норма & \multirow{2}{*}{ I группа } \\
\cline { 1 - 2 } 2 & лёгкая дисфункция & \\
\hline 3 & умеренная дисфункция & II группа \\
\hline 4 & средне-тяжёлая дисфункция & III группа \\
\hline 5 & тяжёлая дисфункция & \\
\hline
\end{tabular}

Таблица 2

Точки акупунктуры при лечении нейропатий лицевого нерва

\begin{tabular}{|c|c|c|}
\hline Дистальные точки & Точка выхода лицевого нерва & Местные точки \\
\hline Время воздействия 20-25 мин & $\begin{array}{c}\text { Время воздействия } \\
20-25 \text { мин }\end{array}$ & $\begin{array}{c}\text { Время воздействия } \\
1-5 \text { мин }\end{array}$ \\
\hline P7, E36, GI11, GI4, E40, RP6 & $\begin{array}{c}\text { TR17 } \\
\text { При болях в области сосцевидного } \\
\text { отростка }\end{array}$ & $\begin{array}{c}\text { V1, VB14, VB1, E1-E7, TR21, } \\
\text { GI19-20, IG18-19, VB2, PN1,2,3 }\end{array}$ \\
\hline
\end{tabular}

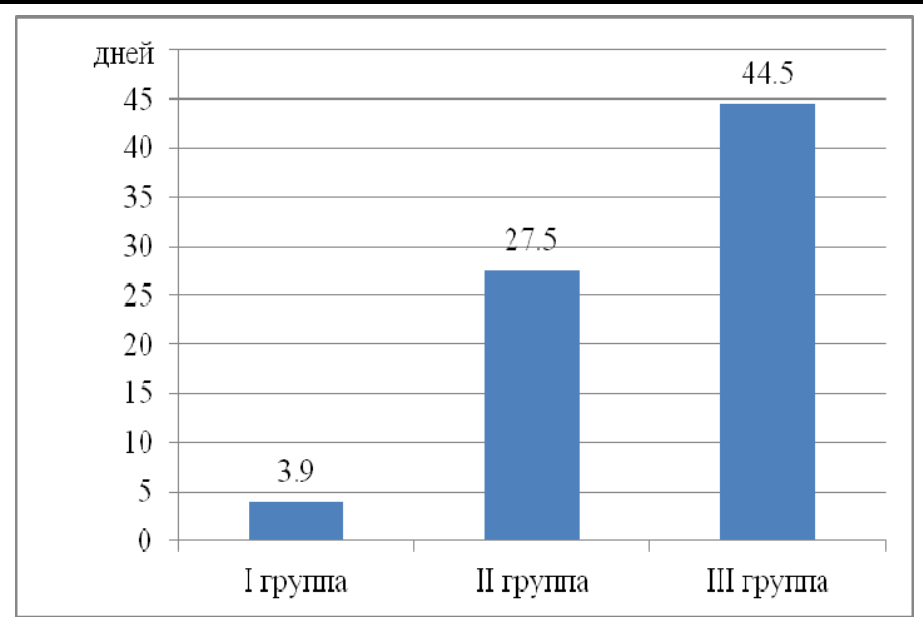

Рис. 1. Длительность заболевания по группам

\begin{tabular}{|c|c|c|c|c|c|c|c|c|}
\hline $\begin{array}{c}\text { Первьци } \\
\text { курс } \\
\text { леченця } \\
7 \text { сеансов }\end{array}$ & 5-7 дней & $\begin{array}{c}\text { Второй } \\
\text { курс } \\
\text { леченшя } \\
7 \text { сеансов }\end{array}$ & 10-14 дней & $\begin{array}{c}\text { Третий } \\
\text { курс } \\
\text { леченця } \\
7 \text { сеансов }\end{array}$ & 21-30 дней & $\begin{array}{c}\text { Четвертьй } \\
\text { курс } \\
\text { леченця } \\
7 \text { сеансов }\end{array}$ & 45-60 дней & $\begin{array}{c}\text { Пятьц̆ } \\
\text { курс } \\
\text { леченця } \\
7 \text { сеансов }\end{array}$ \\
\hline
\end{tabular}

Рис. 2. Схема лечения

терапии в группе I привело к выздоровлению у 94,5 \% пациентов с полным восстановлением функций лицевого нерва.

Bo II группе 68,2 \% пациентам была проведена рефлексотерапия в течение двух курсов и у $23,7 \%$ - трех. В III группе менее трети пациентов $(28,3 \%)$ положительно ответили на два курса рефлекотерапии, 47,1 \% - на три и 3,9 \% - на четыре курса и более.

Следует указать, что полное выздоровление не наступило у 5,3 \% пациентов в I группе, у 8,5 \% - во II группе и у 20 \% - в III группе.

\section{Выводы}

1. Иглоукалывание является важной частью комплексного лечения нейропатий лицевого нерва. Предложенная схема лечения дает возможность оптимизировать реабилитацию нейропатий лицевого нерва на основе миотонизирующего (восстановление функций пораженной мимической мускулатуры), миорелаксирующего, аналгетического, седативного и иммуномодулирующего эффектов.

2. Раннее применение акупунктуры (в течение 1-30 дней) показало наилучшие результаты в виде восстановления двигательного дефицита мимической мускулатуры. 
3. При небольшой давности нейропатии лицевого нерва рефлексотерапия в среднем с 2-3 курсами приводила к быстрому восстановлению утраченных функций.

4. При более длительной форме невропатии лицевого нерва с тяжелым поражением 4-6 класca (H-S шкала) после 150 дней с момента заболевания количество схем лечения с рефлексотерапией может увеличиваться до 6-8 курсов с частичным восстановлением функций лицевого нерва. Необходимо продолжать лечение с учетом сроков назначения повторных курсов лечения. Наблюдается восстановления двигательных дефектов мимической мускулатуры после пяти месяцев (150 дней) от начала заболевания.

Перспективы дальнейших исследований. Будет продолжен поиск путей оптимизации лечения нейропатий лицевого нерва, направленных на улучшение проводимости лицевого нерва, восстановление функции мимических мышц и предупреждение развития мышечной контрактуры.

\section{Литература}

1. Здыбский В.И. Рефлексотерапия при некоторых заболеваниях периферической нервной системы / В.И. Здыбский // Міжнар. неврол. ж. - 2012. - № 4. C. 144-145.

2. Концепція "збуджувального" і "гальмівного" методів у традиційній китайській медицині: загальний сенс, застосування у разі голковколювання та при інших методах рефлексотерапії / Г.М. Чуприна, Є.Л. Мачерет, О.О. Коркушкот [та ін.] // Міжнарод. неврол. ж. 2009. - № 8. - C. 21-37.

3. Коршняк В.О. Комплексна терапія невропатії лицевого нерва в ранній та пізній відновний періоди В.О. Коршняк // Укр. вісн. психоневрол. - 2011. Т. 19, Вип. 3 (68). - С. 17-18.

4. Кугуракова Г.М. Опыт лечения больных нейропатией лицевого нерва в условиях отделения восстановительного лечения / Г.М. Кугуракова, К.М. Волкова, С.И. Аблизен // Здравоохранение Чувашии. - 2013. № 1. - С. 61-64.

5. Максимова М.Ю. Невропатия лицевого нерва / М.Ю. Максимова, М.Н. Шаров, М.А. Домашенко // Фарматека: медицинский журнал. Руководства и рекомендации для семейных и терапевтов. - 2011. - № 14. - C. 46-51.

6. Манкевич С.М. Оптимизация методик рефлексотерапии при осложненной нейропатии лицевого нерва в комплексном восстановительном лечении / С.М. Манкевич. - 2012. - Режим доступу до журн.: http:// belmapo.by/downloads/refleksoterapia/2012/ optimizacija_metodic.pdf

7. Маркин С.П. Восстановительное лечение больных с заболеваниями нервной системы / Сергей Петрович Маркин. - М., 2010. - 109 с.

8. Маркин С.П. Невропатия лицевого нерва / С.П. Маркин // Consilium medicum Неврология. - 2010. - № 1. C. 10-14.

9. Маркин С.П. Поражения лицевого нерва в практике врача / С.П. Маркин // Леч. врач. - 2013. - № 9. C. $38-42$.

10. Мироненко Т.В. Нейропатия лицевого нерва у лиц пожилого возраста: лечение и профилактика осложнений [Електронний ресурс] / Т.В. Мироненко // Здоров'я України. - 2010. Режим доступу до журн.: http://health-ua.com/pics/pdf / N_2010_1/47.pdf

11. Пітик M.I. Характер і динаміка електронейроміографічних показників системи "лицьовий нерв мімічні м'язи" під час лікування невропатії лицьового нерва у дітей: матеріали науково-практичної конференції ["Сучасні аспекти діагностики та лікування захворювань нервової системи"] (Київ, 2526 вересня 2014 року) / М.І. Пітик, І.І. Ліскевич // Укр. неврол. ж. - 2014. - № 3/4. - С. 113-114.

12. Пітик М.І. Невропатія лицевого нерва: особливості патогенезу, діагностики й лікування в дітей та підлітків / М.І. Пітик / Міжнар. неврол. ж. - 2009. № 1 (23). - C. 85-90.

13. Суровых С.В. Асимметрия лица. Малоинвазивные методики коррекции последствий поражения лицевого нерва / С.В. Суровых, О.Р. Орлова, Е.В. Саксонова // Инъекц. мет. в косметол. - 2012. - № 3. - С. 31-40.

14. Такенов Ж.Т. Особенности лечения периферической нейропатии лицевого нерва в бестриггерном (остром) периоде [Електронный ресурс] / Ж.Т. Такенов, Б.А. Бекбаев, Ю.Б. Джекатова, А.Х. Хадыс // Вестн. КАЗНМУ. - 2013 - Режим доступу до журн.: http:// kaznmu.kz/press/wp-content/uploads /2013/03/.pdf

15. Яременко А.И. Сложности реабилитации пациентов с параличом мимической мускулатуры / А.И. Яременко, О.Ю. Петропавловская, Н.В. Пахомова // Эксперим. и клин. дерматокосметол. - 2014. - № 1. - С. 47-50.

16. Baugh R.F. Clinical practice guideline: Bell's palsy / R.F. Baugh // Otolaryngol Head Neck Surg. - 2013. №149(3 Suppl). - P. 1-27.

17. Vogell A. Bilateral Bell palsy as a presenting sign of preeclampsia / A. Vogell // Obstet Gynecol. - 2014. - № 124 (2 Pt 2 Suppl 1). - P. 459-461.

18. Zalagh M. Contralateral facial nerve palsy following mandibular second molar removal: is there co-relation or just coincidence? / M. Zalagh // Pan. Afr. Med. J. - 2014. № $18 .-$ P. 173 .

\section{ЕФЕКТИВНІСТЬ ЛІКУВАННЯ НЕЙРОПАТІЇ ЛИЦЬОВОГО НЕРВА МЕТОДОМ РЕФЛЕКСОТЕРАПІї}

\section{І.Д. Ладна}

Резюме. Досліджені оптимальні терміни і курси лікування хворих з нейропатіями лицьового нерва різного ступеня тяжкості. Комплексне лікування нейропатій лицьового нерва проводилося 3 використанням рефлексотерапії (голковколювання). За результатами дослідження визначені оптимальні терміни і кількість курсів. Метод рефлексотерапії є більш ефективним при зверненні пацієнтів у більш ранній період захворювання. При тривало існуючих нейропатіях необхідно провести п'ять і більше курсів рефлексотерапії. Ефект лікування залежав від тривалості захворювання і часу початку лікування.

Ключові слова: нейропатії, лицьовий нерв, рефлексотерапія.

\section{EFFICIENCY OF TREATMENT OF FACIAL NEUROPATHY BY REFLEXOTHERAPY}

\section{I.D. Ladna}

Abstract. Optimal timing and treatments of patients with facial neuropathy (Bell's palsy) of varying severity were 
studied. Comprehensive treatment of facial neuropathy was carried out using acupuncture (acupuncture). The study is to determine the optimal timing and number of treatment course. The method of acupuncture is more effective for the patient in the earlier period of the disease. Five or more courses of acupuncture should be done with long-existing neuropathy. The effect of treatment depended on the duration of illness and the beginning time of treatment.

Key words: neuropathy, facial nerve, reflexology.

Medical academy of postgraduate education (Kharkiv)

Рецензент - д. мед. н. І.І. Кричун

Buk. Med. Herald. - 2015. - Vol. 19, № 1 (73). - P. $92-96$

Надійшла до редакції 15.01.2015 року

\section{(С) И.Д. Ладная, 2015 \\ УДК 616.24-002.1-008/.071-085.835.56 \\ О.І. Лемко, Д.В. Решетар, Г.М. Павлович \\ ГАЛОАЕРОЗОЛЬТЕРАПІЯ В РЕАБІЛІТАЦІЇ ХВОРИХ НА НЕГОСПІТАЛЬНІ ПНЕВМОНІЇ: КЛІНІЧНО-ФУНКЦІОНАЛЬНІ АСПЕКТИ}

ДУ «Науково-практичний медичний центр «Реабілітація» МОЗ України», м. Ужгород

Резюме. На основі клінічно-функціональних досліджень обгрунтовано доцільність використання галоаерозольтерапії у відновлювальному лікуванні реконвалесцентів після негоспітальних пневмоній. Вивчена

Вступ. На сьогодні негоспітальна пневмонія (НП) посідає одне 3 провідних місць у структурі бронхо-легеневої патології зі збереженням тенденції до підвищення захворюваності $[3,12]$. Незважаючи на достатній арсенал сучасних ефективних протимікробних препаратів, НП все-таки залишається широко поширеним захворюванням, яке приносить значні економічні збитки [3, 9]. Зважаючи на це, останніми роками даному захворюванню приділяється особлива увага в багатьох країнах світу, в тому числі і в Україні [3]. Клініка пневмоній за останні роки помітно змінилася, i, в першу чергу, це пов'язано зі збільшенням випадків (до 3040 \%) їх затяжного перебігу, що пов'язують із порушенням загальних i локальних адаптаційнозахисних механізмів людини та виникненням антибіотикорезистентних штамів мікроорганізмів [2, 10]. Водночас дослідження функції зовнішнього дихання (ФЗД) у хворих на НП здійснюється відносно рідко. Можливо, це зумовлено відсутністю необхідності застосування дослідження респіраторної функції легень для первинного встановлення діагнозу пневмонії. Проте відомо, що у хворих на НП досить часто реєструються значні порушення вентиляційної функції легень, що може мати несприятливе прогностичне значення щодо розвитку хронічної патології бронхо-легеневої системи і визначати необхідність реабілітаційного лікування [4].

Незважаючи на застосування сучасних антибактеріальних засобів, досягнутий прогрес у лікуванні хворих на НП, пошук шляхів оптимізації лікування продовжується. Доведено, що навіть за умови адекватного антибактеріального лікування, повне одужання, за даними комп'ютерної

(C) О.І. Лемко, Д.В. Решетар, Г.М. Павлович, 2015 ефективність різних режимів галоаерозольтерапії у взаємозв'язку з наявністю обструкції бронхів.

Ключові слова: негоспітальні пневмонії, галоаерозольтерапія.

томографії високої роздільної здатності, спостерігається тільки у 28,5 \% хворих [7] і, тим більше, не вирішує проблеми функціонального відновлення бронхо-легеневої системи, що може бути причиною залишкових клінічних проявів і небажаних віддалених наслідків $[5,11]$. Тому постає питання використання засобів реабілітаційної медицини, спрямованих на відновлення функціональних резервів організму людини, знижених внаслідок хвороби, шляхом застосування немедикаментозних засобів $[6,8]$.

У даному аспекті перспективним $\epsilon$ використання галоаерозольтерапії (ГАТ), саногенна спрямованість якої доведена при лікуванні хронічних бронхітів, хронічного обструктивного захворювання легень, бронхіальної астми. Механізми лікувального впливу галоаерозолю включають гіперосмолярну стимуляцію, яка зумовлює покращання реологічних властивостей мокротиння, стимуляцію війкового епітелію і відновлення мукоциліарного кліренсу, що забезпечує відновлення дренажної функції бронхів. Аерозоль кам'яної солі здійснює бактерицидний вплив, який веде до санації бронхіального дерева, що, в комплексі 3 покращанням дренажної функції, забезпечує зниження активності запального процесу в бронхо-легеневій системі і сприяє відновленню функціонування імунної системи [1].

Мета дослідження. На основі клінічнофункціональних даних обгрунтувати доцільність використання галоаерозольтерапії у відновлювальному лікуванні хворих на негоспітальні пневмонії, апробувати різні режими лікування в цього конти- 